\title{
PARAFIA OPIEKI NAJŚWIETSZEJ MARYI PANNY W SIEHNIEWICZACH W DIECEZJI PIŃSKIEJ W ŚWIETLE WIZYTACJI Z 3 PAŹDZIERNIKA 1926 ROKU
}

\begin{abstract}
Streszczenie
Pierwotna świątynia parafialna pw. Opieki Najświętszej Maryi Panny w Siehniewiczach, w diecezji łucko-brzeskiej pochodzi z połowy XVI wieku. Świątynię murowaną ufundowali dla tej parafii Józef i Maria Prozorowie w 1785 roku. Spalona w 1915 roku przez Rosjan, w 1922 roku została odbudowana staraniem proboszcza ks. Izydora Niedroszlańskiego i ludzi dobrej woli. W II Rzeczypospolitej parafia w Siehniewiczach należała do erygowanej w 1925 roku diecezji pińskiej. Historia parafii i sporządzony jej inwentarz, zarówno kościelny, jak i zaplecza gospodarczego, zostały opracowane na wizytację kanoniczną parafii w Siehniewiczach dokonaną 3 października 1926 roku przez ordynariusza diecezji pińskiej Zygmunta Łozińskiego.

Słowa kluczowe: historia Kościoła; historia diecezji pińskiej; historia parafii w Siehniewiczach; inwentarze parafialne; beneficjum parafialne
\end{abstract}

Kościół parafialny w Siehniewiczach został ufundowany w 1548 roku przez Floriana i Annę Radogoskich jako drewniana świątynia pw. Opieki Najświętszej Maryi Panny. W drugiej połowie XVIII wieku (1785) wystawili w Siehniewiczach świątynię murowaną wojewodowie litewscy Józef i Maria z Chaleckich Prozorowie ${ }^{1}$.

* Ks. Waldemar W. Żurek SDB - dr hab. historii Kościoła, prof. KUL w Ośrodku Archiwów, Bibliotek i Muzeów Kościelnych; e-mail: zurek@kul.pl

https://orcid.org/0000-0002-5602-5077

${ }^{1}$ Prozor Józef herbu własnego (1723-1788) - od 1755 roku był wojskim kowieńskim, od następnego roku posłem na sejm kowieński, w 1762 roku objął funkcję generała-majora armii Wielkiego Księstwa Litewskiego. Dwa lata później został starostą kowieńskim i posełem na sejm konwokacyjny powiatu kowieńskiego. W latach 1774-1781 był kasztelanem witebskim, a następnie (1781-1787) wojewodą witebskim. Do 1741 roku zdobył wykształcenie za granicą - w Akademii Rycerskiej w Lunéville. Otrzymał patent porucznika piechoty Księstw Lotaryngii i Baru. Na Sejmie rozbiorowym w 1775 roku należał do Komisji Skarbowej Wielkiego Księstwa Litewskiego. W 1777 
Parafia posiadała patronat szlachecki i należała do dekanatu Szereszów, w diecezji łuckiej-brzeskiej, w województwie brzeskolitewskim ${ }^{3}$. W XIX wieku parafia należała do dekanatu Prużana i posiadała kaplice w Międzylesiu i Sielec$\mathrm{ku}^{4}$. W czasie I wojny światowej (1915) świątynia została spalona przez Rosjan. W 1922 roku została odbudowana przez ówczesnego właściciela majątku i dworu w Siehniewiczach - barona Hugo Neuhoffa-Leya, przy wsparciu innych dobrodziejów i parafian, pod kierunkiem ówczesnego proboszcza ks. Izydora Niedroszlańskiego ${ }^{5}$.

roku był członkiem Departamentu Skarbowego Rady Nieustającej. Z pierwszą małżonką Felicjanną Niemirowicz-Szczytt miał trzech synów (Karola, Antoniego, Ignacego Kajetana) i dwie córki (Petronelę i Mariannę). Po śmierci Felicjanny poślubił w 1767 roku Aleksandrę Zaranek, która urodziła dwie córki (Barbarę i Różę). Trzecią jego żoną była Marianna Chalecka, wdowa po Adamie Szujskim. Z. Zielińska, Józef Prozor, w: Polski Słownik Biograficzny (dalej: PSB), t. 28, Wrocław-Łódź 1984-1985, s. 532.

${ }^{2}$ Patronat - to ogół praw nadawanych przez władzę kościelną wiernym fundującym kościół, kaplicę lub beneficjum oraz tym, którzy od nich to prawo nabyli. Z nich najważniejsze było prawo podawania (prezentowania) biskupowi kandydata na objęcie beneficjum kościelnego, czyli udzielania prezenty na odpowiednie beneficjum. Patronem mogła być osoba duchowna, świecka, osoba innego niż katolickie wyznanie. Patronat mógł być mieszany: duchowno-świecki. Mógł być personalny, należący do osoby lub realny - przypisany do posiadanego majątku nieruchomego. Kościoły położone w Rzeczypospolitej o znanym prawie patronatu posiadały: patronat szlachecki (szlachty i magnatów), patronat duchowny - należący do osób i instytucji duchownych (najczęściej do biskupów i klasztorów), patronat królewski, książęcy, mieszczański, patronat Uniwersytetu Jagiellońskiego i patronat cesarski (na Śląsku). W niewielkiej liczbie występował w parafiach patronat mieszany: duchowno-szlachecki, duchowno-królewski, królewsko-szlachecki, mieszczańsko-szlachecki, szlachecko-uniwersytecki i królewsko-mieszczański. Prawo patronatu nazywano „podawaniem” patronów, których potocznie określano kolatorami. Przywileje patronów dotyczyły zewnętrznego ich wyróżnienia spośród innych wiernych (pierwsze miejsce w świątyni, najbliżej wielkiego ołtarza, ławka kolatorska). Patronowi przysługiwało pierwsze miejsce w procesjach, na których prowadził celebransa pod rękę oraz miał prawo umieścić swój herb w kościele, ucałować krzyż lub relikwie świętych. Prawo patronatu stanowiące ograniczenie wolności Kościoła (np. przy powierzaniu urzędów kościelnych) definitywnie zostało zniesione przez prawodawstwo kościelne po Soborze Watykańskim II. L. Królik, Organizacja diecezji tuckiej i brzeskiej od XVI do XVIII wieku, Lublin 1983, s. 287; S. Litak, Kościót łaciński w Rzeczypospolitej około 1772 roku, Lublin 1996, s. 78-79; S. Tymosz, Patronat, prawo patronatu, w: Encyklopedia katolicka, t. 15, red. E. Gigilewicz, Lublin 2011, kol. 60-63.

${ }^{3}$ L. Królik, Organizacja diecezji tuckiej i brzeskiej od XVI do XVIII wieku, oprac. M. Dębowska, wyd. 2, Biały Dunajec-Ostróg 2017, s. 31; Litak, Kościót taciński, s. 386.

${ }^{4}$ Siehniewicze, w: Stownik geograficzny Królestwa Polskiego i innych krajów słowiańskich, t. 10, red. B. Chlebowski, W. Walewski, Warszawa 1889, s. 518.

${ }^{5}$ Ks. Niedroszlański Izydor (1887-1950) - kapłan diecezji pińskiej. W 1911 roku przyjął święcenia kapłańskie. W 1921 roku został proboszczem w Siehniewiczach. Od połowy lipca 1930 roku pełnił obowiązki proboszcza parafii św. Andrzeja Apostoła w Wyszkach, w dekanacie Bielsk Podlaski, rejon Brańsk. Równocześnie obsługiwał (pełnił obowiązki rektora) kaplicę na cmentarzu w Pulsach (kościół filialny). W Wyszkach z polecenia ks. Nidroszlańskiego naprzeciw trybuny 1-majowej ustawiono krzyż udekorowany kwiatami, co zostało uznane przez władze komunistyczne jako wystąpienie antyradzieckie i działanie kontrrewolucyjne. Na tej parafii ks. Nieroszlański pracował do 1948 roku. Elenchus ecclesiarum et cleri dioecessis pinsceensis pro Anno Domini 1928, Pinsci 
Według spisu powszechnego z 1921 roku w Siehniewiczach (wieś i folwark) mieszkało 468 mieszkańców: rzymokatolików 424 osoby, prawosławnych 38, wyznania mojżeszowego 6. Pod względem narodowościowym 441 osób deklarowało się jako Polacy, 21 jako Białorusini, 6 jako Żydzi ${ }^{6}$.

Po II wojnie światowej i przesunięciu granicy polskiej na linię Bugu, Siehniewicze pozostały w granicach Białoruskiej Socjalistycznej Republiki Radzieckiej. Władze komunistyczne republiki zamknęły w 1949 roku świątynię katolicką w Siehniewiczach. Dzięki determinacji wiernych i duchowieństwa w 1989 roku jednonawowa świątynia w Siehniewiczach została przywrócona do celów kultowych. Współcześnie Siehniewicze położone są w obwodzie (województwie) brzeskim, rejonie (powiecie) Bereza, od 1991 roku w Republice Białorusi ${ }^{7}$.

Akt wizytacji pasterskiej z 1926 roku w rzymskokatolickim parafialnym kościele został sporządzony na podstawie danych przygotowanych przez proboszcza ks. Izydora Niedroszlańskiego, który doprowadził w 1925 roku do odbudowy świątyni po pożarze w 1915 roku.

\section{Opis fizyczny dokumentu rękopiśmiennego}

„Akt wizytacji Pasterskiej z 1926 roku”

Dokument rękopiśmienny składa się z czterech luźnych kart o wymiarach $448 \times 355 \mathrm{~mm}$ złożonych wzdłuż na pół, tworząc osiem kart $(224 \times 355 \mathrm{~mm})$, tj. 16 stron. Papier jest maszynowy o barwie kremowej, drukowany w tzw. 1 linię o niebieskim odcieniu. Tekst naniesiony pismem czytelnym, pochylonym $\mathrm{w}$ prawo, wypisanym czarnym atramentem lekko już spłowiałym, znajduje się na ośmiu stronach: 2 i w $1 / 3$ strony 8 , natomiast strony: 1 i 10-12 nie są zapisane. Na stronach 6-8 widoczne są ręczne dopisy czerwoną i niebieską kredką. Strony są nienumerowane.

Stan zachowania - listopad 2016 roku.

Dokument został poddany zabiegom konserwatorskim. Ubytki uzupełniono papierem odpowiadającym gramaturze i kolorystyce dokumentu, brzegi i złożenie kart wzmocniono bibułką japońską. Karty zostały przyklejone klejem.

Dokument zabezpieczony jest tekturową teczką.

1928, s. 97, Spis kościołów i duchowieństwa diecezji pińskiej w R. P. 1933 i 1934, Pińsk 1933, s. 6465, Spis kościołów i duchowieństwa diecezji pińskiej w R. P. 1939, Pińsk 1939, s. 60; L. Mikhailik, Kościót katolicki na Grodzieńszczyźnie 1939-1956, Warszawa 2008, s. 102-103; Z. Rostkowski, Historia parafii pw. św. Andrzeja Apostoła w Wyszkach, w: „Niedziela. Tygodnik Katolicki”, http:// niedziela.pl/wydruk/28896/nd, (dostęp: 20.08.2019).

${ }^{6}$ Siehniewicze, pl.wikipedia.org/wiki/, (dostęp: 15.03.2020).

${ }^{7}$ G. Rąkowski, Ilustrowany przewodnik po zabytkach kultury na Białorusi, Warszawa 1997, s. $212-213$.

${ }^{8}$ Oryginał księgi znajduje się w ADD, Zespół Archiwum Parafii Siehniewicze, sygn. III/I/1 (Odnaleziony w Archiwum Parafii Wyszki). 


\section{TEKST KSIĘGI: „Akt wizytacji Pasterskiej z 1926 roku”}

Dnia 3 października 1926 roku odbył kanoniczną wizytę parafji Siehniewicze miejscowy Ordynarjusz Jego Biskupia Mość X. Biskup Z[ygmunt] Łoziński ${ }^{9}$.

Przybył z Kiwatycz przez st[ary] Błudeń do Siehniewicz dnia 3 października rano godz. $10 \mathrm{~m}$ [inut] $15 \mathrm{w}$ towarzystwie kanonika ks. H[enryka] Humnickiego ${ }^{10}$.

Spotkał Go przed bramą z chlebem i solą przedmową miejscowy ziemianin p. Hugo baron Neuhoff - Ley, miejscowy proboszcz ks. Izydor Niedroszlański, dziekan Prużański ks. A[ntoni] Beszta-Borowski ${ }^{11}$, XX [=księża] W[ładysław] Mar-

${ }^{9}$ Bp Łoziński Zygmunt (1870-1932) - teolog, ordynariusz diecezji mińskiej, pierwszy biskup erygowanej w 1925 roku diecezji pińskiej, Sługa Boży. Urodził się w Boracinie k. Nowogródka. Wstąpił do seminarium duchownego w Petersburgi w 1889 roku, od 1891 roku kontynuował tam studia w Akademii Duchownej. Święcenia kapłańskie przyjął w 1895 roku. Był wykładowcą w seminarium duchownym z Pisma św. i homiletyki. W latach 1898-1900 został skazany na banicję za odmowę uczestniczenia w nabożeństwie prawosławnym. Przebywał w klasztorze karnym w Agłomie na Łotwie. Po ułaskawieniu pracował w duszpasterstwie: w Smoleńsku, Tule, Rydze, Kalwarii koło Mińska (proboszcz), w parafii katedralnej w Mińsku. Usunięty z Mińska za przyjmowanie unitów do Kościoła katolickiego, podjął wykłady w Akademii Duchownej Petersburgu i kontynuował studia biblijne (Monachium, Rzym, Jerozolima, Rzym). W czasie I wojny światowej był kapelanem jeńców wojennych. W 1917 roku został ordynariuszem reaktywowanej diecezji mińskiej. Sakrę biskupią przyjął w 1918 roku w Warszawie. Po wejściu w grudniu 1918 roku Armii Czerwonej do Mińska ukrywał się. Powrócił do miasta w sierpniu 1919 roku. Po odzyskaniu przez Polskę niepodległości wydał książkę: Chrześcijańska miłość Ojczyzny i praca narodowa (Grodno 1919). Po proklamowaniu Białoruskiej SRR ponownie aresztowany w 1919 roku (w Moskwie). Zwolniony w 1921 roku (traktat ryski) organizował w Nowogródku życie religijne w polskiej części diecezji mińskiej. Od 1925 roku pierwszy biskup diecezji pińskiej. W 1929 roku zwołał pierwszy synod diecezji pińskiej. Zmarł w Pińsku w opinii świętości. W 1957 roku rozpoczęto w Rzymie jego proces beatyfikacyjny. J. Misiurek, Łoziński Zygmunt, w: Encykopedia katolicka, t. 11, red. E. Ziemann, Lublin 2006, kol. 554-555.

${ }^{10}$ Ks. Humnicki Henryk (1873-1959) - kapłan diecezji mińskiej, następnie diecezji pińskiej, proboszcz, od 1924 roku kanclerz kurii w Pińsku, wikariusz kapitulny diecezji pińskiej 1946-1950. Święcenia kapłańskie przyjął w 1899 roku. Od 1922 roku był proboszczem Parafii Wniebowzięcia NMP w Łunińcu, dziekanem dekanatu Łuniniec i kanonikiem kapituły mińskiej. Od 1933 roku pełnił obowiązki proboszcza katedry w Mińsku i dziekana mińskiego. W 1935 roku przeniósł się w „stan spoczynku” i rezydował przy kościele św. Karola w Pińsku. W 1943 roku ordynariusz mianował do wikariuszem generalnym. W 1945 roku jako Polak został wysiedlony z granic Białoruskiej SRR do Polski Ludowej, ze wskazaniem ewakuacji w Bielsku Podlaskim, gdzie nadal pełnił funkcję wikariusza generalnego. Elenchus ecclesiarum et cleri saecularis ac regularis dioecesis minscensis pro Anno Domino 1924, [Minsci 1924], s. 23, 42.

${ }^{11}$ Ks. Beszta-Borowski Antoni (ur. 1880) - kapłan diecezji pińskiej. Święcenia kapłańskie przyjął w 1904 roku. Kanonik honorowy i dziekan prużański do 1927 roku. Od 1927 roku był proboszczem Parafii Narodzenia NMP i św. Mikołaja w Bielsku i dziekanem bielskim. 
kowicz ${ }^{12}$, Z[enon] Szymkiewicz ${ }^{13}$ wsch[odniego] obrządku, ceremoniarz Gzyszewicz, pomocnik celremoniarza B. Małecki i subdyakon wsch[odniego] obrządku Zapolski.

Po spotkaniu odbył się ingres do miejscowego kościoła, gdzie miejscowy proboszcz ks. I[Zydor] Niedroszlański złożył sprawozdanie Jego Biskupiej Mości z obecnego stanu parafji, na co odpowiedział Jego Biskupia Mość zachęcając ludność miejscowej parafii do dalszej odbudowy kościoła i kościoła duchowego.

Potem odbyło się żałobne nabożeństwo i celebra pontyfikalna, podczas celebry Jego Biskupia Mość wygłosił naukę.

Po mszy św. przerwa obiadowa, następnie o godz. 4 min. 30 wygłosił kanclerz kanonik ks. H[enryk] Humnicki naukę o bierzmowaniu, po nauce jego Biskupia Mość udzielił sakramentu bierzmowania dla 540 osób, po bierzmowaniu Jego Biskupia Mość odprawił różaniec, po skończonym nabożeństwie przeprowadził rewizję olejów św., chrzcielnicy, piscyny ${ }^{14}$ i oglądał kościół, na tem zakończyły się czynności Ordynarjusza dnia 3 października.

Dnia 4 października b.r. wysłuchał mszy św. odprawionej przez ks. kanclerza [Henryka Humnickiego] po mszy św. oglądał ogród po ś. p. Annie Mikulskiej i o godz. 9 rano podpisał księgi metrykalne wyjeżdżając w towarzystwie ks. kanclerza [ks. Hernyka Humnickiego] do Sielca i rozdzielił obrazki na pamiątkę wizytacji.

[s. 2] Historia Siehniewickiego Rzymsko-kat[olickiego] paraf[ialnego] kościoła z 1926 roku

Siehniewicki rz-kat[olicki] paraf[ialny] kościół należy obecnie do diecezji pińskiej, województwa poleskiego, starostwa i dekanatu próżańskiego, niegdyś należał do diecezji Łucko-Brzeskiej. Nie wiadomo kiedy i przez kogo był wybudowany drewniany kościół w Siehniewiczach jednak można przypuszczać, że pochodził on z XVII wieku, jak widać z ksiąg metrykalnych znajdujących się w archiwum kościelnym, a mianowicie: księgi ślubne z 1657 roku i księgi chrzestne z 1676 roku.

Obecny kościół w Siehniewiczach murowany został wybudowany w 1785 roku przez Józefa i Marję z Hrabiów Galickich Prozorów, wojewodów litewskich,

${ }^{12}$ Ks. Markowicz Władysław (ur. 1886) - kapłan diecezji pińskiej. Święcenia kapłańskie przyjął 1911 roku. Od 1924 roku był proboszczem Parafii Trójcy Przenajświętszej w Szereszowie, dekanat Prużana oraz pełnił obowiązki proboszcza w kościele filialnym św. Jana Nepomucena w Nepomucenach (Annopol). Spis kościołów i duchowieństwa diecezji pińskiej w R. P. 1933 i 1934, s. 153,155 .

${ }^{13}$ Ks. Szymkiewicz Zenon (ur. 1896) - kapłan obrządku wschodniego - unita. Święcenia kapłańskie przyjął w 1923 roku. Od 1933 roku pełnił obowiązki proboszcza parafii obrządku wschodniego na terenie parafii rzymskokatolickiej parafii Małoryta, dekanat Brześć. Tamże, s. 83, 186.

${ }^{14}$ Piscyna - w średniowieczu piscyną określano kamienną misę umieszczoną w niszy w okolicy ołtarza. Była ona wykorzystywana do puryfikacji naczyń liturgicznych po sprawowanej Mszy Świętej, z której woda z resztakami komunikantów była odprowadzana do gruntu. R. Wróbel, Piscina, w: Encyklopedia katolicka, t. 15, red. E. Giglilewicz, Lublin 2011, kol. 722. 
pod wezwaniem Opieki Matki Boskiej (Patrocini BMV), jak widać z bulli Papieża Piusa VI wydanej 26 listopada 1786 roku wyżej wymienionemu Józefowi Prozorowi. plice.

Rozmiar kościoła Siehniewickiego...; przy kościele wybudowane są dwie ka-

Kościół zwrócony głównym wejściem do zachodu, facjata ${ }^{15}$ kościoła w prostej linii, przy której znajdują się dwie wieże kwadratowe, a trzecia mała okrągła nad wielkim ołtarzem. Wierzchnia część wież zrobiona z desek i pokryte są blachą, na wieżach żelazne krzyże. Przy wieżach znajdują się dwie rynny drewniane pokryte blachą.

W 1899 r. kosztem pani [Anny] Mikulskiej cały kościół był odnowiony, jak również na wieżach i zakrystiach gonty dano nowe. $Z$ frontu kościoła 2 duże okna, bocznych okien 6, w których przy wielkim ołtarzu 2 w 1899 r. kosztem pani [Anny] Mikulskiej zrobiono żelazne ramy i oszklono różnokolorowem szkłem. W kaplicach również po dwa małe okna o żelaznych ramach (witraże). W zakrystiach 2 weneckie okna z kratą żelazną wychodzą na zewnątrz kościoła i 2 do części ołtarzowej. W lewej wieży dwa okna i nad zakrystiami w szczytach od [s. 3] wielkiego ołtarza 2 małe okna; ogólna liczba okien 19. Wszystkich drzwi w kościele 11.

Sufit w kościele, zakrystiach, kaplicach i wieżach, drewniany malowany w 1899 r. Posadzka w całym kościele z tafli cementowych, a w prezbiterium i zakrystiach ze sztucznego marmuru.

Archiwum kościelne znajduje się w lewej wieży. W prawej wieży umieszczone są dzwony. Organ nowy o 10-ciu głosach zbudowany w 1900 r. kosztem p. [Anny] Mikulskiej przez firmę Jana Szymańskiego w Warszawie ${ }^{16}$.

Utrzymanie. Siehniewicki kościół zaliczony do IV klasy ${ }^{17}$ i otrzymuje od Rządu $275 \mathrm{rb}$ [=rubli] na utrzymanie kościoła i służby kościelnej.

${ }^{15}$ Facjata - dawniej frontowa ściana budynku, fasada.

${ }^{16}$ Polski organmistrz Jan Szymański (1828-1892) rozpoczął w 1861 roku swoją działalność w Częstochowie. W 1868 roku przeniósł się do Warszawy. Zamieszkał przy ulicy Chłodnej i tam prowadził firmę organmistrzowską, a kontynuowali ją po jego śmierci synowie. Szymański był jednym z kilku znanych polskich organmistrzów. Zasadnicze zmiany w konstrukcji i strukturze brzmieniowej organów (wiatrownice głosowe, brzmienie „orkiestrowe”), jakie następowały XIX wieku na Zachodzie, docierały i do Polski, chociaż z pewnym opóźnieniem. W drugiej połowie XIX wieku działało wiele warsztatów organmistrzowskich, m.in. M. Mielczarski w Łowiczu, L. Blomberg i Synowie w Warszawie, Jan Szymański i Synowie w Warszawie. Nowości wymienionych organmistrzów polegały na zastosowaniu wiatrownic stożkowych i wolno stojących kontaurów przed szafą organową. Prototyp tak zbudowanych organów został umieszczony w kościele św. Jana Chrzciciele w Warszawie na Bródnie. M. Szymanowska, Organy (2. W Polsce), w: Encyklopedia katolicka, t. 14, red. E. Gigilewicz, Lublin 2010, kol. 775-777.

${ }^{17} \mathrm{~W}$ działalności pastoralnej Kościoła ustawodawstwo carskie ze stycznia 1843 roku dzieliło biskupstwa w Cesarstwie Rosyjskim na trzy klasy. Od tych klas wyznaczono wysokość uposażenia diecezji, biskupa i duchownych. Pod koniec tego roku kolejny ukaz carski określił uposażenie parafii i niższego duchowieństwa diecezjalnego. Na podstawie tego ukazu parafie zostały podzielone na pięć klas. Proboszczom z poszczególnych klas wyznaczono pensję etatową od 235 do 600 rubli w skali roku. Ponadto proboszczom pozostawiono określony areał gruntów albo w zamian specjalny zasiłek ze skarbu państwa. Tak więc większość parafii posiadała uposażenie według klasy V. Z racji wypełniania swoich obowiązków i przeprowadzanych wizytacji parafii dziekani pobierali dodatkowo 5\% od pensji proboszczowskiej. Litak, Kościół łaciński, s. 78-79. 
W roku 1915 kościół siehniewicki z wszystkimi budynkami został spalony przez wojska rosyjskie, pozostały tylko mury a w r. 1925 został odbudowany. Zdjęto $1 \mathrm{~m} 50 \mathrm{~cm}$ starego zepsutego muru, na całym kościele i wieżach kościelnych, a dano nowy. Ułożono nowe belki, zaciągnięto nowe krokwie i sporządzono wiązania dachowe i pokryto cały kościół nowymi gontami, wieże zaś - na których umieszczono żelazne krzyże, pokryto blachą pocynkowaną (sic). Przy wieżach od kościoła umieszczono dwie rynny drewniane wyłożone blachą ocynkowaną. Gzymsy $^{18}$ są częściowo pokryte nową blachą ocynkowaną częściowo zaś żelazną. Cały kościół wewnątrz i zewnątrz otynkowany i wybielony wapnem. Wszystkich drzwi w kościele 11. Wielkie drzwi głównego wejścia podwójne, umocowane na żelaznych zawiasach bez zamku, zamykają się tylko haki. Od głównego wejścia w lewej wieży umieszczono schody, które prowadzą na chór. Na chórze jedne drzwi pojedyncze umocowane na żelaznych zawiasach bez zamku, tylko zamykają się na haczyk od wewnątrz chóru. Drugie drzwi na chórze, które prowadzą do prawej wieży gdzie było archiwum. Drzwi nie ma tylko futryna wmurowana. $\mathrm{Na}$ chórze umieszczona fisharmonia firmy Hofberg - J[ohan] Grosspietsch ${ }^{19} \mathrm{o}$ registrach.

[s. 4.] Przy wejściu z babińca ${ }^{20}$ są wmurowane trzy futryny lecz bez drzwi. Dwoje bocznych mniejszych i jedne duże vis a' vis gł[ównego] wejścia. W lewej zakrystii dwoje drzwi pojedynczych na zawiasach i z wewnętrznymi zamkami. W prawej zakrystii wchodząc $\mathrm{z}$ kościoła drzwi nie ma tylko wmurowana futryna. Wychodząc na cmentarz kościelny z zakrystii są drzwi pojedyncze na zawiasach i z wewnętrznym zamkiem.

Ogólna liczba okien w kościele 17. Jedno okno w szczycie z frontu kościoła, 1 okno na chórze, 1 okno w prawej wieży gdzie było archiwum, 2 okna w lewej wieży gdzie były dzwony lecz bez futryn, zabite deskami - 2 okna weneckie w dużym kościele, po 2 okna małe o żelaznych ramach w kaplicach, 1 okno weneckie w prawej i $1 \mathrm{w}$ lewej zakrystii: i 2 okna w szczytach nad zakrystiami i dwa duże okna w prezbiterium. Wszystkie okna są oszklone.

Posadzka w całym kościele poprawiona.

${ }^{18}$ Gzyms - poziomo biegnący profilowany występ ściany, zdobiący wewnętrzne i zewnętrzne mury budynku oraz niektóre elementy wyposażenia wnętrza, np. piece, kominki. Element ozdobny budowli.

${ }^{19} \mathrm{~W}$ Wrocławiu było tyle firm produkujących fortepiany, ilu było rdzennych mieszkańców Niemców. Przemysł fortepianowy był więc bardzo rozwinięty. Pierwszego znanego w ogóle mistrza produkującego instrumenty klawiszowe - G. Baumgartena notowano w 1635 roku. Manufakturę przemysłową produkującą fortepiany zapoczątkował Johann Karl Traugott Berndt, którego firma „Traugott Berndt” była jedną z najdłużej działających w latach 1837-1945 w tym mieście. Nagromadzona z latami dokumentacja firmy, jak i sama firma, uległa zniszczeniu w 1945 roku. Johannes Grosspietsch prowadził we Wrocławiu magazyn, wypożyczalnię i sklep pianin i fortepianów. Następnie zorganizował własną firmę produkującą pianina. Po jego śmierci w 1901 roku firmę prowadził m.in. Robert Heckel oraz rodzina. W 1941 roku firma Grosspietsch świętowała swoje 75-lecie działalności. Produkcja organów w przedwojennym Wrocławiu, http://arspolonica.ocross. net/produkcja-fortepianow-we-wroclawiu/, (dostęp: 15.03.2020).

${ }^{20}$ Babiniec - staropolska nazwa przedsionka kościelnego (kruchty) przeznaczonego dla kobiet żebrzących, w którym nauk katechetycznych mogli słuchać np. kacerze i Żydzi. Większe kościoły miały kilka wejść, a przy nich babińce boczne. 


\section{Beneficjum kościelne}

Siehniewicki rz-kat[olickiego] paraf[ialny] kościół posiada nadanej ziemi w 1842 r. (33 dziesięciny $\left.{ }^{21}\right) 37$ ha $2422 \mathrm{~m}^{2}$, z których według planu przypada pod ogrody place i zabudow[ania] 1 ha $9352 \mathrm{~m}^{2}$. Grunta orne 19 ha $8932 \mathrm{~m}^{2}$, tąki 7 ha $0226 \mathrm{~m}^{2}$, pastwiska 3 ha $7087 \mathrm{~m}^{2}$, cmentarz kościelny $2607 \mathrm{~m}^{2}$, zarośla 1 ha 3258 $\mathrm{m}^{2}$, ląka mokra 1 ha $5033 \mathrm{~m}^{2}$, stawy $2055 \mathrm{~m}^{2}$, rowy $1829 \mathrm{~m}^{2}$, drogi 1 ha $2043 \mathrm{~m}^{2}$.

\section{Zabudowania gospodarcze}

1) Dom mieszkalny rozmiar $15 \times 6$ metrów składający się z czterech 4 pokoi, przedpokoju, kuchni, pokoju dla służby, spiżarni i sionki.

2) Obora, stajnia i wozownia pod jednym dachem, rozmiar $18 \times 8 \mathrm{mtr}$.

3) Stodoła na zboże o dwóch drzwiach, rozmiar $20 \times 9 \mathrm{mtr}$.

4) Chlew dla chlewni zbudowany z opołó $\mathrm{w}^{22}$ rozmiar $6 \times 4 \mathrm{mtr}$.

Do parafii siehniewickiej należą gminy: Rewiatycze, Międzylesie i część gminy Malecz.

\section{[s. 5] Inwentarz kościelny}

Pozostało po spalonym kościele:

\begin{tabular}{|l|c|}
\hline Monstrancja & 1 \\
\hline Dzwon z cmentarza grzebalnego - obecnie przy kościele & 1 \\
\hline Dzwonek mały & 1 \\
\hline Lichtarz żelazny pod paschał & 1 \\
\hline Żelazko do wypiekania opłatków (stare) & 1 \\
\hline Figury żelazne: M[atki] Bożej, św. Heleny, św. Michała Archanioła & 3 \\
\hline Tabernakulum & 1 \\
\hline
\end{tabular}

Nabyto do kościoła:

\begin{tabular}{|l|c|}
\hline Kielich mały, srebrny złocony & 1 \\
\hline Puszka platerowana $^{\mathrm{a}}$ do Sanctissimum [=Najświętszego Sakramentu] & 2 \\
\hline Krzyżyk mosiężny złocony & 1 \\
\hline Lichtarze wernikowe $^{\mathrm{b}}$ małe & 2 \\
\hline
\end{tabular}

a Platerowanie - pokrywanie metalu mniej szlachetnego warstwą materiału szlachetniejszego, np. miedź folią srebrną lub złotą, w celu ozdobienia lub zabezpieczenia przed korozją.

b Werniks - przeźroczysta substancja żywiczna, stosowana do zabezpieczania przedmiotów przed wpływami atmosferycznymi.

${ }^{21}$ Dziesięcina - dawna miara powierzchni gruntu. Na terenach zaboru rosyjskiego, które nie tworzyły Królestwa Kongresowego, czyli na wschód od Bugu, w XIX i na początku XX wieku była urzędową miarą powierzchni gruntów. Stosowane były dwie jednostki o tej nazwie: 1) dziesięcina tzw. skarbowa $=10925,2 \mathrm{~m}^{2}$ (1,09252 ha -109 arów, 1,9508 morgów); 2) dziesięcina tzw. większa, nazywana także „dużą” $=14567 \mathrm{~m}^{2}$ (1,4567 hektara). Obie nazwy stosowano równolegle, co stwarzało trudność w przeliczaniu wielkości gruntów na jednostki dzisiejsze.

${ }^{22}$ Opoły drewniane - to zewnętrzne deski z korą i częścią pobocznicy drewna. Są odpadem przecierania drewna przy produkcji tarcicy. 


\begin{tabular}{|c|c|}
\hline Puszka aluminiowa do hostyj & 1 \\
\hline Naczynia z tacką platerowane do Olejów św. & 1 \\
\hline Dzwonek mały & 1 \\
\hline Ampułki szklane & 2 \\
\hline Lampka wisząca przed Sanctissimum [=Najświętszym Sakramentem] & 1 \\
\hline Tabernakulum jesionowe & 1 \\
\hline Figura drewniana duża, $\mathrm{P}[\mathrm{an}]$ Jezus w cierniowej koronie & 1 \\
\hline Figura gipsowa św. Antoniego & 1 \\
\hline Tron z jedwabiu białego do wystawiania Najśw[iętszego] Sakr[amentu] & 1 \\
\hline Żyrandol mosiężny do świec & 1 \\
\hline Mszał żałobny & 1 \\
\hline Mszał święty & 1 \\
\hline Patena pozłacana do chorych & 1 \\
\hline Bursy $^{\mathrm{c}}$ do chorych & 2 \\
\hline Krzyż drewniany z figurą Pana Jezusa & 2 \\
\hline Naczynia do wody chrzestnej emaliowane & 1 \\
\hline Baldachim $^{\text {d }} \mathrm{z}$ serwety niebiesk[iej] o 4 drążkach & 1 \\
\hline Welon naramienny jedwabny & 1 \\
\hline \multicolumn{2}{|l|}{ Konfesjonał } \\
\hline \multicolumn{2}{|l|}{ [s.6] } \\
\hline Obraz M. B. Częstochowskiej & 1 \\
\hline Obraz M. B. Bolesnej & 1 \\
\hline Obraz Naj[świętszego] Serca Pana Jezusa & 1 \\
\hline Obrazek mały Matki Bożej N[ieustającej] Pomocy & 1 \\
\hline Obrazek mały Matki Bożej Ostrobramskiej & 1 \\
\hline Chorągiew niebieska z monogr[amem] M[atki] B[ożej] & 1 \\
\hline
\end{tabular}

${ }^{\mathrm{c}}$ Bursa - parament liturgiczny w kształcie kwadratowej teczki. Używany jest podczas sprawowania Mszy Świętej lub do przenoszenia Najświętszego Sakramentu (wiatyku). Do bursy mszalnej wsuwa się korporał, aby ze względu na jego styczność z Eucharystią okazać specjalną cześć. Używa się bursę dostosowaną do koloru szat liturgicznych danego okresu liturgicznego. Bursa zamknięta służy do przenoszenia Najświętszego Sakramentu do chorych. Z. Zalewski, Bursa, w: Encyklopedia katolicka, t. 2, red. F. Gryglewicz, R. Łukaszczyk, Z. Sułowski, Lublin 1985, kol. 1225-1226.

${ }^{d}$ Baldachim - to w kościele katolickim osłona nad ołtarzem głównym, stallami, amboną lub fotelem dostojników. Jest to osłona w kształcie daszka, stała lub przenośna. Występuje w formie kopuły, nadwieszona lub podparta kolumnami, zwieńczona akcentem plastycznym. Od strony wewnętrznej czasami ozdobiona malowanym gwiaździstym niebem. Najczęściej baldachim jest używany w procesjach teoforycznych nad Przenajświętszym Sakramentem. F. Mąkinia, M. Pisarzak, Baldachim, w: Encyklopedia katolicka, t. 1, red. F. Gryglewicz, R. Łukaszczyk, Z. Sułowski Lublin 1985, kol. 1275-1276.

${ }^{\mathrm{e}}$ Komoda - mebel skrzyniowy z szufladami do przechowywania paramentów kościelnych. 


\begin{tabular}{|l|c|}
\hline Komody $^{\mathrm{e}}$ & 2 \\
\hline Krzesło & 1 \\
\hline Dywany samodziałowe & 3 \\
\hline Dywan wełniany gruby & 1 \\
\hline Klęcznik mah[oniowy] z bronzy & 1 \\
\hline Lichtarze miedziane małe & 2 \\
\hline Skarbonka blaszana & 1 \\
\hline Miseczka do wody & 1 \\
\hline Kanony na ołtarz ${ }^{\text {(komplet) }}$ & 3 \\
\hline Całun żałobny & 1 \\
\hline Pieczęć kościelna z poduszką & 1 \\
\hline Waskulum szklane & 1 \\
\hline Wycinacz do komunikantów & 1 \\
\hline Portatyl ${ }^{\mathrm{h}}$ w ołtarzu nowy z 1922 r. & 1 \\
\hline Poduszki pod mszał & 2 \\
\hline Ołtarzyk stary do procesji & 1 \\
\hline Puszka pozłacana pęknięta z krzyżem ułamanym & 1 \\
\hline Patena pozłacana, ma podstawę złamaną & 1 \\
\hline Figura (Zmartwychwstałego) & 1 \\
\hline Paschał & 1 \\
\hline
\end{tabular}

${ }^{\mathrm{f}}$ Kanony - trzy tablice oprawne na przedsoborowych ołtarzach. Jedna, największa umieszczana była na środku ołtarza, dwie mniejsze po bokach. Środkowa tablica zawierała modlitwy odmawiane w czasie Mszy Świętej podczas ofiarowaniu. Tablica po prawej stronie ołtarza, gdzie kapłan obmywał ręce, zawierała Psalm 50 (Lavabo Domine...), a tablica z lewej (tzw. ostatnia) - Ewangelię wg św. Jana.

g Vasculum, waskulum, wasculum (łac. małe naczynko) - naczynie liturgiczne z wodą, głównie stojące przy tabernakulum. Służy do obmywania (ablucji) palców przez szafarza po udzieleniu komunii świętej, bądź umieszczenia w nim drobnych partykuł Najświętszych postaci, bądź upadłej hostii świętej, która rozpuszcza się w znajdującej się w nim wodzie. Vasculum, w: P. Krzyżewski, J. Zjawin, Mały leksykon liturgii, Poznań 2011, s. 152.

${ }^{\text {h }}$ Portatyl - stosowany w liturgii chrześcijańskiej już w III wieku. Od IV wieku zapoczątkowano umieszczanie relikwii świętych w ołtarzu i portatylach. Od końca XIX wieku portatyl musiał zawierać relikwie co najmniej dwóch męczenników. Ich zasklepienia dokonywał biskup. Sprawowanie Eucharystii bez portatyla poza kościołem było zabronione. W czasie wojen funkcję portatyla pełnił płócienny korporał z zaszytymi relikwiami. Reforma odnowy liturgii po Soborze Watykańskim II zniosła obowiązek stosowania portatylu. K. Cichoń, M. Konieczny, Portatyl, w: Encyklopedia katolicka, t. 16, red. E. Gigilewicz, Lublin 2012, kol. 7-8. 


\section{Ornaty}

\begin{tabular}{|l|c|}
\hline Biały z słuckich pasówi (ofiara pani Szemiothowej) & 1 \\
\hline Białe zwyczajne (1 o b[iało]-sbrebr[nych] bok[ach] i 1 o żółt[to]-sreb[rnych] bok[ach]) & 2 \\
\hline Źółty & 1 \\
\hline
\end{tabular}

\section{[s. 7]}

\begin{tabular}{|l|c|}
\hline Kapa fioletowa & 1 \\
\hline Alby & 2 \\
\hline Pasów do alb & 2 \\
\hline Komże duże & \\
\hline Komże małe & \\
\hline Stuła fioletowa z drugiej strony biała & \\
\hline Stuła czerwona & \\
\hline Obrusów na ołtarz & \\
\hline Ręczników & \\
\hline Płótna (namiotak) & \\
\hline Korporałów $^{j}$ & \\
\hline Palek $^{\mathrm{k}}$ & \\
\hline Puryfikatorzy $^{1}$ & \\
\hline
\end{tabular}

\section{Księgi metryczne}

Chrzestne od 1916 r. do 1921 r.

Chrzestne od 1921 do 1925 r. i z 1926 w użyciu

Ślubne od 1917 do

Pogrzebowe od 1916 do

Egzaminów przedślubnych.

Księga konwertytów od 1917 r.

Księga kroniki parafii siehniewickiej

Spis parafialny

i Pas słucki - element ozdobny polskiego stroju szlacheckiego, to szeroki, ozdobny pas jedwabny, często przetykany srebrnymi lub złotymi nićmi. Nazwa pochodzi od ośrodka produkcji w żonej w 1746 roku przez Michała Kazimierza Radziwiłła w manufakturze w Słucku, 100 kilometrów na południe od Mińska. Pas był ozdobnym elementem stroju szlacheckiego, zwany inaczej pasem kontuszowym, noszony do kontusza. Pasy słuckie chętnie nosiła szlachta z Rzeczypospolitej Obojga Narodów. Pas ukazywał na ile zasobny był jego właściciel. Odrodzenie zapomnianego rzemiosła, pasy kontuszowe, http://twojezaglebie.pl/pasy-kontuszowe-xxi-wieku/ (dostęp: 15.03.2020).

${ }^{\mathrm{j}}$ Korporał - w liturgii katolickiej to lniana kwadratowa serweta usztywniona, którą kładzie się na ołtarz i na niej ustawia się kielich w czasie sprawowania Mszy Świętej i monstrancję z Najświętszym Sakramentem.

${ }^{\mathrm{k}}$ Palka - kwadratowe, usztywnione przykrycie kielicha mszalnego, wykonane z płótna, służące do ochrony Postaci eucharystycznych przed zanieczyszczeniem.

${ }^{1}$ Puryfikaterz - w liturgii katolickiej biały, płócienny ręczniczek służący w czasie odprawiania Mszy Świętej do wycierania kielicha mszalnego i puszki z Najświętszym Sakramentem. 
[s. 8] Wzięto z kościoła kobryńskiego od ks. dziekana Ignacego Rossołowskiego $^{23}$, do kościoła siehniewickiego w 1916 r. stare paramenta kościelne ${ }^{24}$ :

\section{Ornaty:}

\begin{tabular}{|l|c|}
\hline Biały & $\underline{1}$ \\
\hline Zielony & $\underline{1}$ \\
\hline Fioletowy & $\underline{1}$ \\
\hline Czerwony & $\underline{1}$ \\
\hline Czarny & $\underline{1}$ \\
\hline
\end{tabular}

\section{Kapy:}

\begin{tabular}{|l|c|}
\hline Biała & 1 \\
\hline Zielona & 1 \\
\hline Czerwona & 1 \\
\hline Czarna & 1 \\
\hline
\end{tabular}

\section{Stuły:}

\begin{tabular}{|l|c|}
\hline Fioletowa & 1 \\
\hline Zielona & 1 \\
\hline Czarna & 1 \\
\hline Welon na puszkę & \\
\hline Obrusy na ołtarz & \\
\hline Komże & 2 \\
\hline Alby & \\
\hline Humerały & \\
\hline Pasek do alby & \\
\hline Ręcznik & \\
\hline
\end{tabular}

${ }^{\mathrm{m}}$ Humerał (łac. humerus - ramię, barki) - część stroju liturgicznego w postaci białej hustki nakładanej na ramiona pod albę, która zakrywa laicki ubiór duchownego koło szyi. Nie jest obowiązkowym elementem stroju duchownego podczas sprawowania liturgii.

${ }^{23}$ Ks. Rossołowski Ignacy (ur. 1869) - wraz z parafianami prowadził budowę kościoła parafialnego w parafii Kobylnik (dawniej Medal) w diecezji wileńskiej. W 1897 roku po położeniu i poświęceniu kamienia węgielnego rozpoczęto budowę murowanej świątyni św. Andrzeja Apostoła, którą ukończono w 1901 roku. Jego konsekracji dokonał biskup wileński Edward Ropp w 1904 roku. Natomiast 1908 w roku przebywało w byłym klasztorze franciszkańskim w Grodnie zamienionym na więzienie 10 księży, w tym ks. Ignacy Rosołowski, liczący lat 39. Catalogus Ecclesiarum et Ccleri Archidioecesis Vilnensis pro Anno Domini 1936, Vilnae 1933, s. 100-101; J. Kurczewski, Biskupstwo wileńskie, Wilno 1912, s. 207.

${ }^{24}$ Paramenty kościelne wzięto do Siehniewicz z kościoła parafialnego w Kołkach po spaleniu kościoła w Siehniewiczach przez wojska rosyjskie w 1915 roku. 


\begin{tabular}{|l|c|}
\hline Ręczniczki & \\
\hline Korporały & \\
\hline Puryfikaterzy & \\
\hline Palki & \\
\hline Dywan fabryczny & \\
\hline Krzyż procesjonalny metalowy & 1 \\
\hline Puszka miedziana (mała okrągła) & \\
\hline [s. 9] & \\
\hline Lichtarze małe & \\
\hline Kociołek do wody & \\
\hline Łódka z łyżeczką do kadzielnicy & \\
\hline Kadzielnica (trybularz) & \\
\hline Tacki małe metalowe & \\
\hline Ampułka metalowa do chrztu & \\
\hline Krzyżyk czarny mały & \\
\hline
\end{tabular}

ks. proboszcz Izydor Niedroszlański

\section{BIBLIOGRAFIA}

\section{Źródla}

Catalogus ccclesiarum et cleri archidioecesis vilnensis pro Anno Domini 1936, Vilnae 1933.

Elenchus ecclesiarum et cleri saecularis ac regularis dioecesis minscensis pro Anno Domino 1924, [Minsci 1924].

Elenchus ecclesiarum et cleri dioecessis pinsceensis pro Anno Domini 1928, Pinsci 1928.

\section{Opracowania}

Królik Ludwik, Organizacja diecezji tuckiej i brzeskiej od XVI do XVIII wieku, wyd. 2, red. M. Dębowska, Biały Dunajec-Ostróg 2017

Litak Stanisław, Kościót łaciński w Rzeczypospolitej około 1772 roku, Lublin 1996.

Mąkinia Franciszek, Pisarzak Marian, Baldachim, w: Encyklopedia katolicka, t. 1, red. F. Gryglewicz, R. Łukaszczyk, Z. Sulowski, Lublin 1985, kol. 1275-1276.

Mikhailik Larysa, Kościót katolicki na Grodzieńszczyźnie 1939-1956, Warszawa 2008.

Misiurek Jerzy, Łoziński Zygmunt, w: Encyklopedia katolicka, t. 11, red. E. Ziemann, Lublin 2006, kol. 554-555.

Cichoń Krzysztof, Konieczny Mariusz, Portatyl, w: Encyklopedia katolicka, t. 16, red. E. Gigilewicz, Lublin 2012, kol. 7-8.

Rąkowski Grzegorz, Ilustrowany przewodnik po zabytkach kultury na Białorusi, Warszawa 1997. 
Siehniewicze, w: Słownik Geograficzny Królestwa Polskiego, t. 10, Warszawa 1889, s. 518. Spis kościołów i duchowieństwa diecezji pińskiej w R. P. 1933 i 1934, Pińsk 1933.

Spis kościołów i duchowieństwa diecezji pińskiej w R. P. 1939, Pińsk 1939.

Szymanowska Maria, Organy (2. W Polsce), w: Encyklopedia katolicka, t. 14, red. E. Gigilewicz, Lublin 2010, kol. 775-777.

Tymosz Stanisław, Patronat, prawo patronatu, w: Encyklopedia katolicka, t. 15, red.

E. Gigilewicz, Lublin 2011, kol. 60-63.

Vasculum, w: Krzyżewski Piotr, Zjawin Jacek, Mały leksykon liturgii, Poznań 2011, s. 152.

Wróbel Robert, Piscina, w: Encyklopedia katolicka, t. 15, red. E. Gigilewicz, Lublin 2011, s. 722 .

Zalewski Zbigniew, Bursa, w: Encyklopedia katolicka, t. 2, red. R. Gryglewicz, R. Łukaszuk, Z. Sułowski, Lublin 1985, kol. 1225-1226.

Zielińska Zofia, Józef Prozor, w: Polski Słownik Biograficzny, t. 28, Wrocław-Warszawa-Kraków 1984-1985, s. 532-534.

\title{
Netografia
}

Odrodzenie zapomnianego rzemiosta, pasy kontuszowe, w: http://twojezaglebie.pl/pasy-kontuszowe-xxi-wieku/ (dostęp: 15.03.2020).

Produkcja organów w przedwojennym Wrocławiu, w: http://arspolonica.ocross.net/produkcja-fortepianow-we-wroclawiu/ (dostęp: 15.03.2020).

Rostkowski Zbigniew, Historia parafii pw. św. Andrzeja Apostoła w Wyszkach, w: „Niedziela", http://niedziela.pl/wydruk/28896/nd (dostęp: 20.08.2019).

Siehniewicze, w: pl.wikipedia.org/wiki/ (dostęp: 15.03.2020).

\section{THE PARISH OF THE PROTECTION OF THE BLESSED VIRGIN MARY IN SIEHNIEWICZE IN THE PIŃSK DIOCESE BASED ON THE VISITATION RECORDS OF 3 OCTOBER 1926}

\begin{abstract}
Summary
The original parish church dedicated to the Protection of the Blessed Virgin Mary in Siehniewicze, in the Lutsk-Brest diocese, dates from the mid-sixteenth century. The masonry church was founded by Józef and Maria Prozorów in 1785 . It was burned in 1915 by the Russians and then rebuilt in 1922, thanks to the efforts of Rev. Izydor Niedroszlański and those who supported him. In the Second Republic of Poland, the parish in Siehniewicze became part of the Pińsk diocese, which was established in 1925. The history of the church and the inventory of the church and the parish property were prepared for the canonical visitation of the parish in Siehniewicze, conducted 3 October 1926 by the ordinary bishop of the Pińsk diocese, Zygmunt Łoziński.
\end{abstract}

Keywords: the history of the Church; the history of the diocese of Pińsk; the history of the parish of Siehniewicze; parish inventories; parish benefice 


\section{ПРИХОД ПОКРОВА ПРЕСВЯТОЙ ДЕВЫ МАРИИ В СЕГНЕВИЧАХ ПИНСКОЙ ЕПАРХИИ В СВЕТЕ ВИЗИТАЦИИ ОТ 3 ОКТЯБРЯ 1926 Г.}

\section{Содержание}

Первый приходской храм Покрова Пресвятой Девы Марии в Сегневичах Луцко-Брестской епархии, возник в середине шестнадцатого века. Каменный храм для прихода был построен на средства Иосифа и Марии Прозоровых в 1785 году. Сожжённый русскими в 1915 году, он был отстроен в 1922 г. усилиями настоятеля о. Исидора Недорошлянского и людей доброй воли. Во времена II Речипосполитой приход в Сегневичах принадлежал Пинской епархии, основанной в 1925 году. История прихода и ее инвентарь, как храмовый, так и хозяйственного обеспечения, были составлены к канонической визитации прихода в Сегневичах, которая была проведена 3 октября 1926 года ординарием Пинской епархии Сигизмундом Лозинским.

Ключевые слова: история Католической Церкви; история Пинской епархии; история прихода в Сегневичах; приходские инвентари; приходские бенефиции

Пераклад Лауры Михайлик

\section{ПАРАФІЯ АПЕКІ НАЙСВЯЦЕЙШАЙ ПАННЫ МАРЫІ Ў СЕГНЕВІЧАХ НА ПАДСТАВЕ ГІСТОРЫ СЕГНЕВЦЦКАГА РЫМА-КАТАЛІЦКАГА ПАРАФІЯЛЬНАГА КАСЦЁЛА З 1926 ГОДА}

\section{Скарачэнне}

Першы парафіяльны касцёл Апекі Найсвяцейшай Панны Марыі ў Сегневічах Луцка-Брэсцкай дыяцэзіi, паўстаў у сярэдзіне шаснаццатага стагоддзя. Каменная святыня для парафіі была пабудавана на сродкі Язэпа і Марыі Прозаравых у 1785 годзе. Спалены рускімі уу 1915 годзе, касцёл быў адбудаваны ў 1922 г. намаганнямі пробашча кс. Ісідара Недарашлянскага і людзей добрай волі. У часы II Рэчыпаспалітай парафія ў Сегневічах належала да Пінскай дыяцэзіi, заснаванай ў 1925 годзе. Верагодна, з гэтай нагоды была напісана кароткая гісторыя парафіі і складзены яе інвентар, як касцельны, так і які тычыцца парафіяльнай маёмасці.

Ключавыя словы: гісторыя Каталіцкага Касцёла, гісторыя Пінскай дыяцэзіі, гісторыя парафіі ў Сегневічах, парафіяльныя інвентары, парафіяльныя бенефіцыі. 